ISSN 0258-7122 (Print), 2408-8293 (Online)

Bangladesh J. Agril. Res. 42(2): 273-288, June 2017

\title{
EFFECT OF VARIED PLANTING TIME AND DEHAULMING ON THE YIELD POTENTIAL, PROCESSING QUALITY AND ECONOMIC BENEFIT IN POTATO*
}

\author{
M. S. ALAM ${ }^{1}$, N. ISLAM ${ }^{2}$, M. J. HOSSAIN ${ }^{3}$, M. S. R. BHUIYAN ${ }^{4}$ \\ AND M. I. HOSSAIN ${ }^{2}$
}

\begin{abstract}
A field experiment was conducted for producing higher processing grade tuber yield and quality by evaluating in relation to different planting times (31 October, 15 and 30 November) and dehaulming dates (80, 90 and 100 days after planting) during 2012-13 potato growing season at Bangladesh Agricultural Research Institute, Gazipur. Results revealed that different growth parameters like plant height, leaves number per hill and foliage coverage were significantly influenced by planting times. Processing and non processing grade tuber number and yield were significantly affected by all the treatments and their interaction. Significantly higher yield of processing grade tuber were recorded in November 15 planting in combination with all the dehaulming dates, ranged from 20.67 to $21.50 \mathrm{t} / \mathrm{ha}$. Processing quality parameters like specific gravity, dry matter, reducing sugar content were significantly varied by planting times, dehaulming dates and their interaction. Whereas the potato chips colour score were not affected by the planting time and dehaulming but all the processing quality parameters were remained in acceptable range. The highest net return (Tk $1,68,404 /$ ha) with a BCR of 1.93 was obtained in November 15 planting with dehaulming at 90 days after planting.
\end{abstract}

\section{Introduction}

The potato (Solanum tuberosum L.) is one of the most important food crop in the world (Braun, 2010). Potato can be cultivated in many regions of the world and used for many purposes. Potato cultivation contributes to meeting the increasing need for food created by world population growth. Potato tubers accumulate large amounts of starch and are low in fat, and their protein content is comparable to that of grains. In addition, potatoes contain vitamin C (RodriguezFalcon et al., 2006). Processing potatoes need some quality such as high dry matter, low reducing sugar etc. It is reported that desirable processing attributes greatly varied with location (Kumar et al., 2003), time of sowing (Kumar et al., 2007), cultivars, time of dehaulming (Marwaha, 1998; Marwaha et al., 2005) and

${ }^{1}$ Senior Scientific Officer, Tuber Crops Research Center (TCRC), Bangladesh Agricultural Research Institute (BARI), Gazipur, ${ }^{2}$ Professor, Department of Horticulture, Sher-e-Bangla Agricultural University, Dhaka, ${ }^{3}$ Director, TCRC, BARI, Gazipur; ${ }^{4}$ Professor, Department of Genetics and Plant Breeding and Pro-Vice Chancellor, Sher-eBangla Agricultural University, Dhaka, Bangladesh.

*Part of $\mathrm{Ph}$. D dissertation of the first author. 
prevailing temperature during crop season (Pandey et al., 2008). Among them, date of planting and haulm killing are the important practices for cultivating processing potatoes. Matured tubers are usually of high specific gravity and this is closely connected with high yield and quality of chips. Moreover, mature potatoes are less susceptible to damage during transport, storage and reconditioning. Maturity of potato tubers is closely connected with the date of planting and harvesting in particular regions, as well as weather condition prevailing in a given year (Lisinka and Leszezynski, 1989). The optimum temperature for potato growth is $15-20^{\circ} \mathrm{C}$, with a lower limit of $5-10^{\circ} \mathrm{C}$ and an upper limit of $25^{\circ} \mathrm{C}$ (Haverkort, 1990; Prange et al., 1990). Temperature and photoperiod during the growing season affect sugar and dry matter content of potatoes and, therefore, the chipping quality (Burton, 1989). Yamaguchi et al. (1964) reported that yield, specific gravity and starch content of tubers were the highest and sugar content lowest, when tubers were grown in soil temperature between 15 and $24^{\circ} \mathrm{C}$, compared with tubers grown at higher temperatures. So, date of planting should be standardized based on the environmental factors for producing processing potato in any region. Delayed planting dates caused yield reduction (Krishnappa, 1991; Peter et al., 1988). Muthuraj and Ravichandran (2014) and Muthuraj et al. (2005) opined that the planting time greatly affected tuber size distribution like- large, medium and small tuber yield in a locality differently within the varieties. Haulm killing is one of the methods used in potato production that regulate tuber size and quality. Dehaulming can be used to obtain a suitable tuber size, strengthen tuber skins before harvesting leading storage quality of potato (Struik and Wiersema, 1999). Interaction between date of planting and date of haulm killing maintained growth period which ultimately affect yield, tuber size distribution and quality. However, information regarding date of planting and dehaulming on processing grade tuber yield and quality is scanty in Bangladesh condition. Under such situations, need was felt to develop optimum planting time and crop growth duration for the maximization of processing grade tuber yield with quality and economical returns to potato growers and processors.

\section{Materials and Method}

This field experiment was conducted at the research field of Tuber Crops Research Center of Bangladesh Agricultural Research Institute, Gazipur during October 2012 to March 2013. The maximum and minimum mean air temperature of $23.1^{\circ} \mathrm{C}$ and $18.2^{\circ} \mathrm{C}$ was in November 2012 and January 2013, respectively. The soil of the experimental field was well drained sandy loam having a $\mathrm{pH}$ of 6.3 . The variety was BARI Alu-28 (Lady Rosetta). The treatment consisted of 3 planting times of October $31\left(D_{1}\right)$, November $15\left(D_{2}\right)$ and November $30\left(\mathrm{D}_{3}\right)$ along with 3 dehaulming dates of $80\left(\mathrm{M}_{1}\right), 90\left(\mathrm{M}_{2}\right), 100$ $\left(\mathrm{M}_{3}\right)$ days after planting (DAP). The treatments were arranged in a factorial 
Randomized Complete Block Design with 3 replications. The unit plot size was $3.0 \mathrm{~m} \times 3.0 \mathrm{~m}$ and tubers were planted at a spacing of $60 \mathrm{~cm} \times 25 \mathrm{~cm}$. Two outer rows of plants were treated as border rows, while the three middle rows in each plot were regarded as experimental row plants. The land was fertilized with 161-32-150-19-4-1.7 kg/ha, respectively of NPKSZnB fertilizers in addition to $6 \mathrm{t} / \mathrm{ha}$ of cowdung (Hossain et al., 2007). The NPKSZnB fertilizers were applied in the forms of urea, triple super phosphate (TSP), muriate of potash (MoP), gypsum, Zinc sulphate and boric acid. The full amount of cowdung, TSP, MoP, gypsum, Zinc sulphate, boric acid, respectively and half of urea was applied at furrow and mixed up with soil by a tine before planting seed tubers. The rest half of urea was applied as top dress at 33 days after planting followed by irrigation. The well pre-sprouted, healthy, whole seed tubers of around $40 \pm 5 \mathrm{~g}$ sized were planted as per treatment in 2012. All other intercultural operations, like irrigation, weeding, earthing up and crop protection measures were adopted as per recommendation of TCRC, BARI. Plant stand was monitored and the final emergence count was taken at 30 days after planting. Dehaulming was done manually as per treatment and potato tubers were harvested after 10 days of dehaulming. Data on growth like plant height, number of compound leaves per hill, stem per hill were taken at 60 DAP from randomly selected 10 plants per plot, and yield per hectare was calculated during harvest from the middle rows yield. Foliage coverage was recorded at 60 DAP by using green method (Groves et al., 2005). Harvested potato tubers were sorted to different size grades of $<40 \mathrm{~mm}$ as non-process grade and $\geq 40 \mathrm{~mm}$ as processing grade. The weight and number of tubers in each size fraction was recorded. Tuber dry matter was estimated just after harvest with dried in oven at $80^{\circ} \mathrm{C}$ to a constant weight. Reducing sugars were estimated following the method of Nelson (1944). For chipping, potatoes were hand peeled and cut into slices of 1.5-1.8 mm thickness with a manual slicing machine. The slices were washed thoroughly in cold water, air dried and immediately fried in soybean oil at $180^{\circ} \mathrm{C}$ till the bubbling on the chip surface stopped. The chips were scored visually for colour and assigned a value on a scale of $1-10$, where 1 being the lightest and 10 dark brown (Ezekiel et al., 2003). The cost of cultivation and gross returns from the crop were calculated on the basis of local market prices of inputs and farm gate price of potato. Net returns (Tk/ha) were worked out by subtracting the total cost of cultivation under each treatment from the gross return of respective treatment. Benefit cost ratio (BCR) was worked out by dividing the gross return with total cost of production (Kumar et al., 2014; Kushwah and Singh, 2011). The data on growth, yield components and yield were statistically analysed by using computer package programme of MSTAT-C and means were compared by using Duncan's Multiple Range Test at 5\% level of significance. 


\section{Results and Discussion Growth attributes}

Nearly $100 \%$ emergence was recorded at 30 days after planting (DAP) and the emergence was not significantly affected by date of planting, dehaulming schedule and their interaction (Table 1). This might be due to around same size and healthy seed tubers were planted. Besides, more or less favourable soil temperature and moisture condition were prevailed same in all the plots. As dehaulming schedule treatments were started after 80 days of planting, so obviously it did not affect plant emergence as well as other growth parameters like plant height, compound leaves per hill, stem per hill and foliage coverage (\%). Plant height was significantly influenced by date of planting. The result showed that plant height decreased as the advancement of date of planting. Thirty first October planting $\left(D_{1}\right)$ recorded the highest plant height $(80.7 \mathrm{~cm})$ as compared to $\mathrm{D}_{2}$ and $\mathrm{D}_{3}$ planting dates (Table 1). These differences in plant height can be attributed to the differences in the prevailing weather conditions. The highest plant height in $\mathrm{D}_{1}$ planting can be attributed to the most favourable environment i.e. long period of high temperature for plant growth during the cropping season. The lowest plant height was recorded at $\mathrm{D}_{3}$ planting can be due to the lower temperature experienced by the plants after emergence compared to other planting dates, thus lower temperature might have reduced allocation of assimilates for growth than the remaining two planting dates. Similar findings have also been reported by Sandhu et al. (2012), Singh and Khurana (1997) and Ezekiel and Bhargava (1992). Leaf number per hill was significantly influenced by date of planting and was insignificant in dehaulming schedule and by the interaction between them (Table 1). The highest number of leaf per hill (67.1) was observed in $\mathrm{D}_{2}$ planting followed by $\mathrm{D}_{1}$ planting (63.5) and they did not differ significantly with each other. The lowest leaf number per hill (55.4) was recorded in $\mathrm{D}_{3}$ planting. This can be ascribed due to first two planting dates experienced more favorable environmental conditions apparently longer period than $\mathrm{D}_{3}$ planting. The leaf number per hill was ranging from 51.1 to 71.8 in the nine treatment combinations but their differences were non-significant. Stem per hill was not significantly influenced by dates of planting and dehaulming and their interactions (Table 1). The stem per hill was ranged from 3.8 to 4.4 in the nine treatment combinations. This might be due to seed tuber size was more or less same. Per cent foliage coverage was not significantly influenced by date of planting, dehaulming schedule and their interaction (Table 1). Around $100 \%$ foliage coverage was recorded by the main effects of date of planting, dehaulming schedule and their interaction. 
Table 1. Effect of dates of planting and dehaulming on growth of potato

\begin{tabular}{c|c|c|c|c|c}
\hline Treatments & $\begin{array}{c}\text { Plant } \\
\text { emergence } \\
(\%)\end{array}$ & $\begin{array}{c}\text { Plant height } \\
(\mathrm{cm})\end{array}$ & $\begin{array}{c}\text { Leaf /hill } \\
(\mathrm{no})\end{array}$ & $\begin{array}{c}\text { Stem/hill } \\
(\text { no. })\end{array}$ & $\begin{array}{c}\text { Foliage } \\
\text { coverage }(\%)\end{array}$ \\
\hline A. Date of planting & & & & & \\
$\mathrm{D}_{1}$ & 99.4 & $80.7 \mathrm{a}$ & $63.5 \mathrm{a}$ & 4.2 & $100.0 \mathrm{a}$ \\
$\mathrm{D}_{2}$ & 99.6 & $69.1 \mathrm{~b}$ & $67.1 \mathrm{a}$ & 4.2 & $100.0 \mathrm{a}$ \\
$\mathrm{D}_{3}$ & 99.8 & $61.1 \mathrm{c}$ & $55.4 \mathrm{~b}$ & 4.0 & $99.3 \mathrm{~b}$ \\
B. Dehaulming schedule & & & & \\
$\mathrm{M}_{1}$ & 99.6 & 70.8 & 62.9 & 4.2 & 99.8 \\
$\mathrm{M}_{2}$ & 99.4 & 69.4 & 62.0 & 4.3 & 99.7 \\
$\mathrm{M}_{3}$ & 99.8 & 70.6 & 61.1 & 4.0 & 99.7 \\
Interaction between A \& $\mathrm{B}$ & 99.3 & 80.8 & 59.2 & 4.2 & 100.0 \\
$\mathrm{D}_{1} \mathrm{M}_{1}$ & 99.7 & 79.6 & 63.1 & 4.0 & 100.0 \\
$\mathrm{D}_{1} \mathrm{M}_{2}$ & 99.3 & 81.9 & 68.1 & 4.4 & 100.0 \\
$\mathrm{D}_{1} \mathrm{M}_{3}$ & 99.7 & 69.0 & 71.8 & 4.1 & 100.0 \\
$\mathrm{D}_{2} \mathrm{M}_{1}$ & 99.0 & 70.0 & 65.4 & 4.1 & 100.0 \\
$\mathrm{D}_{2} \mathrm{M}_{2}$ & 100.0 & 68.3 & 64.2 & 4.1 & 100.0 \\
$\mathrm{D}_{2} \mathrm{M}_{3}$ & 99.7 & 62.8 & 57.7 & 4.2 & 99.3 \\
$\mathrm{D}_{3} \mathrm{M}_{1}$ & 99.7 & 58.7 & 57.4 & 4.1 & 99.0 \\
$\mathrm{D}_{3} \mathrm{M}_{2}$ & 100.0 & 61.7 & 51.1 & 3.8 & 99.0 \\
$\mathrm{D}_{3} \mathrm{M}_{3}$ & 0.79 & 6.19 & 8.65 & 9.29 & 0.35 \\
$\mathrm{CV}_{2}(\%)$ & 0.13 & 1.75 & 1.51 & 0.07 & 0.08 \\
$\mathrm{SE}_{(\mathrm{A} \times \mathrm{B})}$ & 9 & & & \\
\hline
\end{tabular}

Figure(s) in a column having common letter(s) do not differ significantly at $5 \%$ level by DMRT.

$\mathrm{D}_{1}=31$ October, $\mathrm{D}_{2}=15$ November $\& \mathrm{D}_{3}=30$ November , and $\mathrm{M}_{1}=80$ days after planting (DAP), $\mathrm{M}_{2}=90 \mathrm{DAP}, \mathrm{D}_{3}=100 \mathrm{DAP}$

\section{Grades of tubers}

Significantly higher non-processing grade tuber number per hill (4.1) was recorded when the crop was planted at 31 October $\left(D_{1}\right)$ and it differed significantly with the other two planting datesl (Table 2). The data shows that non processing grade tuber number per hill decreased significantly as lengthening the crop growth period by delaying dehaulming (Table 2). The highest number of non processing grade tuber number per hill (3.7) was recorded at $\mathrm{M}_{1}$ (dehaulming at $80 \mathrm{DAP}$ ) and the lowest (2.9) was observed at $\mathrm{M}_{3}$ (dehaulming at $100 \mathrm{DAP}$ ). Similar results were reported by Kumar and Lal (2006). The combined effect of date of planting and dehaulming schedule was significantly influenced non processing grade tuber number per hill (Table 2). The results revealed that non processing grade tuber number per hill was steadily decreased at every planting 
dates by the dehaulming schedule except $\mathrm{D}_{3} \mathrm{M}_{3}$ treatment combination. The highest number of non-processing grade tuber per hill (4.8) was recorded in $D_{1} M_{1}$ closely followed by $D_{1} M_{2}$ (4.6), but the differences were statistically similar. The lowest number of non processing grade tuber per hill (2.7) was observed in $\mathrm{D}_{2} \mathrm{M}_{3}$ followed by $\mathrm{D}_{2} \mathrm{M}_{2}$ and $\mathrm{D}_{3} \mathrm{M}_{2}$. At dehaulming of 80 DAP, the crop period was comparatively short resultant full bulking not completed. As a consequence, non-processing grade tuber number per hill was higher in $D_{1} M_{1}$ and $\mathrm{D}_{1} \mathrm{M}_{2}$ treatment combination.

For processing grade tuber number per hill, the results were reversed in respect of non processing grade tuber number per hill. Processing grade tuber number per hill was highest (4.9) when the crop was planted at November $15\left(\mathrm{D}_{2}\right)$ closely followed by $\mathrm{D}_{3}$ planting, but the differences were non-significant. With regard to dehaulming, processing grade tuber number per hill was the highest (4.8) in $\mathrm{M}_{3}$ (dehulming at 100 DAP) followed by $\mathrm{M}_{2}$ (4.5) and $\mathrm{M}_{1}$ (4.3). The combined effect of date of planting and dehaulming was significantly influenced the processing grade tuber per hill (Table 2). The highest number of processing grade tuber per hill (5.0) was observed in $D_{2} M_{2}$, but it was statistically similar with $D_{2} M_{3}, D_{2} M_{1}$, $D_{1} M_{3}, D_{3} M_{1}, D_{3} M_{2}$ and $D_{3} M_{3}$. The lowest number of processing grade tuber per hill (3.6) was recorded at $D_{1} M_{1}$ which was statistically at par with $D_{1} M_{2}$ (3.7). Total tuber number per hill was not statistically influenced by combined effect of date of planting and dehaulming (Table 2). In that case, total number of tuber per hill was ranged 7.5 to 8.4 .

The highest weight of non processing grade tuber per hill $(97.5 \mathrm{~g})$ was recorded at $\mathrm{D}_{1}$ planting and the lowest $(70.0 \mathrm{~g})$ was observed at $\mathrm{D}_{2}$ planting closely followed by $\mathrm{D}_{3}$ planting $(70.9 \mathrm{~g})$ (Table 2). This might be due to lesser growth period was received by the $\mathrm{D}_{1}$ planting for bulking compared to others that caused smaller size of tuber. The results showed that the increase the crop growth period, the decrease the non-processing grade tuber weight per hill significantly. The highest weight of non-processing grade tuber weight per hill $(90 \mathrm{~g})$ was observed at $\mathrm{M}_{1}$ dehaulming which was at par with $\mathrm{M}_{2}(84.4 \mathrm{~g})$. However, the lowest weight of non-processing grade tuber $(64.0 \mathrm{~g})$ was observed in $\mathrm{D}_{3}$ planting. It might be due to lengthen the crop growth period, which provided more accumulation of photosynthates for tuber bulking resulted more bigger size tuber and lessen the non-processing grade tuber . The combined effect of date of planting and dehaulming was significantly influenced the non processing grade tuber weight per hill (Table 2). The highest weight of non-processing grade tuber per hill $(114.4 \mathrm{~g})$ was recorded in $\mathrm{D}_{1} \mathrm{M}_{1}$ which was also remained at par with $\mathrm{D}_{1} \mathrm{M}_{2}(111.1 \mathrm{~g})$. Whereas, the lowest $(67.6$ g) was observed in $\mathrm{D}_{3} \mathrm{M}_{2}$ followed by $\mathrm{D}_{3} \mathrm{M}_{3}(68.0 \mathrm{~g})$ and these were not significant. 
Table 2. Effect of dates of planting and dehaulming on yield components of potato

\begin{tabular}{|c|c|c|c|c|c|c|}
\hline \multirow{2}{*}{ Treatments } & \multicolumn{3}{|c|}{$\begin{array}{c}\text { Grades of tubers per hill (by } \\
\text { number) }\end{array}$} & \multicolumn{3}{|c|}{$\begin{array}{l}\text { Grades of tubers per hill (by wt. } \\
\qquad(\mathrm{g}))\end{array}$} \\
\hline & $<40 \mathrm{~mm}$ & $\geq 40 \mathrm{~mm}$ & Total & $<40 \mathrm{~mm}$ & $\geq 40 \mathrm{~mm}$ & Total wt. \\
\hline \multicolumn{7}{|c|}{ A. Date of planting } \\
\hline $\mathrm{D}_{1}$ & $4.1 \mathrm{a}$ & $4.0 \mathrm{~b}$ & 8.1 & $97.5 \mathrm{a}$ & $242.6 \mathrm{c}$ & $340.1 \mathrm{c}$ \\
\hline $\mathrm{D}_{2}$ & $2.9 \mathrm{~b}$ & $4.9 \mathrm{a}$ & 7.8 & $70.0 \mathrm{~b}$ & $327.3 \mathrm{a}$ & $396.9 \mathrm{a}$ \\
\hline $\mathrm{D}_{3}$ & $3.0 \mathrm{~b}$ & $4.8 \mathrm{a}$ & 7.8 & $70.9 \mathrm{~b}$ & $292.7 \mathrm{~b}$ & $364.6 \mathrm{~b}$ \\
\hline \multicolumn{7}{|c|}{ B. Dehaulming schedule } \\
\hline $\mathrm{M}_{1}$ & $3.7 \mathrm{a}$ & $4.2 \mathrm{~b}$ & 7.9 & $90.0 \mathrm{a}$ & $272.7 \mathrm{c}$ & 362.7 \\
\hline $\mathrm{M}_{2}$ & $3.4 \mathrm{~b}$ & $4.5 \mathrm{ab}$ & 8.0 & $84.3 \mathrm{a}$ & $286.9 \mathrm{~b}$ & 371.2 \\
\hline $\mathrm{M}_{3}$ & $2.9 \mathrm{c}$ & $4.8 \mathrm{a}$ & 7.6 & $63.9 \mathrm{~b}$ & 303.9 a & 367.8 \\
\hline \multicolumn{7}{|c|}{ Interaction between A \& B } \\
\hline $\mathrm{D}_{1} \mathrm{M}_{1}$ & $4.7 \mathrm{a}$ & $3.6 \mathrm{~b}$ & 8.4 & $114.4 \mathrm{a}$ & $207.8 \mathrm{f}$ & $322.1 \mathrm{~d}$ \\
\hline $\mathrm{D}_{1} \mathrm{M}_{2}$ & $4.6 \mathrm{a}$ & $3.7 \mathrm{~b}$ & 8.3 & $111.1 \mathrm{a}$ & $231.8 \mathrm{e}$ & $342.9 \mathrm{c}$ \\
\hline $\mathrm{D}_{1} \mathrm{M}_{3}$ & $2.9 \mathrm{bc}$ & $4.7 \mathrm{a}$ & 7.6 & $67.1 \mathrm{bc}$ & $288.3 \mathrm{~d}$ & $355.4 \mathrm{bc}$ \\
\hline $\mathrm{D}_{2} \mathrm{M}_{1}$ & $3.3 \mathrm{~b}$ & $4.6 \mathrm{a}$ & 7.9 & $78.4 \mathrm{~b}$ & $317.6 \mathrm{bc}$ & $396.0 \mathrm{a}$ \\
\hline $\mathrm{D}_{2} \mathrm{M}_{2}$ & $2.7 \mathrm{c}$ & $5.0 \mathrm{a}$ & 7.7 & $74.1 \mathrm{~b}$ & $326.7 \mathrm{ab}$ & $400.8 \mathrm{a}$ \\
\hline $\mathrm{D}_{2} \mathrm{M}_{3}$ & $2.7 \mathrm{c}$ & $5.0 \mathrm{a}$ & 7.7 & $56.5 \mathrm{c}$ & $337.5 \mathrm{a}$ & $394.1 \mathrm{a}$ \\
\hline $\mathrm{D}_{3} \mathrm{M}_{1}$ & $3.1 \mathrm{bc}$ & $4.7 \mathrm{a}$ & 7.8 & $77.0 \mathrm{~b}$ & $292.9 \mathrm{~d}$ & $369.9 \mathrm{~b}$ \\
\hline $\mathrm{D}_{3} \mathrm{M}_{2}$ & $2.9 \mathrm{bc}$ & $5.0 \mathrm{a}$ & 7.9 & $67.6 \mathrm{bc}$ & $302.4 \mathrm{~cd}$ & $370.0 \mathrm{~b}$ \\
\hline $\mathrm{D}_{3} \mathrm{M}_{3}$ & $3.0 \mathrm{bc}$ & $4.7 \mathrm{a}$ & 7.7 & $68.0 \mathrm{bc}$ & $285.8 \mathrm{~d}$ & $353.8 \mathrm{bc}$ \\
\hline CV (\%) & 6.85 & 7.60 & 4.74 & 7.99 & 3.17 & 2.45 \\
\hline $\mathrm{SE}(\mathrm{A} \times \mathrm{B})$ & 0.15 & 0.11 & 0.08 & 1.13 & 1.09 & 1.54 \\
\hline
\end{tabular}

Figure(s) in a column having common letter(s) do not differ significantly at $5 \%$ level by DMRT.

$<40 \mathrm{~mm}=$ Non processing grade tuber, $\geq 40 \mathrm{~mm}=$ Processing grade tuber.

$\mathrm{D}_{1}=31$ October, $\mathrm{D}_{2}=15$ November $\& \mathrm{D}_{3}=30$ November , and $\mathrm{M}_{1}=80$ days after planting (DAP), $\mathrm{M}_{2}=90 \mathrm{DAP}, \mathrm{D}_{3}=100 \mathrm{DAP}$.

Processing grade tuber weight per hill was the highest $(327.3 \mathrm{~g})$ in $\mathrm{D}_{2}$ planting followed by $\mathrm{D}_{3}$ planting (292.7 $\mathrm{g}$ ) and the lowest $\left(242.6 \mathrm{~g}\right.$ ) in $\mathrm{D}_{1}$ planting (Table 2 ). On the contrary, the results showed that the early the dehaulming, the decrease the weight of processing grade tuber per hill significantly. In that case, the weight of processing grade tuber per hill was ranged between 272.7 to 303.9 g. The maximum weight of processing grade tuber per hill $(337.5 \mathrm{~g})$ was recorded in $\mathrm{D}_{2} \mathrm{M}_{3}$ which was statistically similar to $\mathrm{D}_{2} \mathrm{M}_{2}(326.7 \mathrm{~g})$ while the 
lowest (207.8 g) was observed in $\mathrm{D}_{1} \mathrm{M}_{1}$. Similar to processing grade tuber weight per hill, the highest total weight of tuber per hill (396.9 g) was obtained with $\mathrm{D}_{2}$ planting, which was significantly higher than all other planting dates (Table 2). However, total weight of tuber per hill did not significantly influence by dehaulming. These results revealed that processing and non processing grade tubers differed due to bulking period that regulates photosynthates transferred to tubers. The results are supported by the earlier findings of Kushwah and Singh (2008). There was significant variation was observed in total weight of tuber per hill by the combined effect of date of planting and dehaulming (Table 2). The highest weight of total tuber per hill $(400.8 \mathrm{~g})$ was obtained in $\mathrm{D}_{2} \mathrm{M}_{2}$ followed by $\mathrm{D}_{2} \mathrm{M}_{1}(399.1 \mathrm{~g})$ and $\mathrm{D}_{2} \mathrm{M}_{3}(394.1 \mathrm{~g})$ and these were not differed significantly. However, the lowest (340.2 g) was observed in $\mathrm{D}_{1} \mathrm{M}_{1}$.

\section{Yield}

Yield of non-processing grade tubers was statistically differed with dates of planting and dehaulming and their interaction (Table 3). The highest yield of non-processing grade tuber $\left(7.2 \mathrm{t} / \mathrm{ha}\right.$ ) was recorded in $\mathrm{D}_{1}$ planting, which was significantly higher than the other two planting dates and it was around $32 \%$ of the total produce. Similarly, the higher yield of non- processing grade tuber (6.5 $\mathrm{t} / \mathrm{ha}$ ) was obtained with dehaulming at 80 DAP $\left(\mathrm{M}_{1}\right)$, which was significantly higher than all other dehaulming dates, it was around $28 \%$. These results corroborate the earlier findings of Singh and Kushwah (2010) where higher production of small size tubers obtained at earlier dehaulming may be due to lesser time available for bulking. The maximum yield of non processing grade tuber ( $8.8 \mathrm{t} / \mathrm{ha})$ was obtained in $\mathrm{D}_{1} \mathrm{M}_{1}$ followed by $\mathrm{D}_{1} \mathrm{M}_{2}(8.4 \mathrm{t} / \mathrm{ha})$ and these were statistically similar and it was around $42 \%$ and $35 \%$ of the total yield, respectively (Table 3 ). Whereas, the lowest (3.8 t/ha) was observed in $\mathrm{D}_{2} \mathrm{M}_{3}$ which was around $26 \%$. The data shows that at every planting date, yield of nonprocessing grade tuber was decreased by the delayed of dehaulming except $\mathrm{D}_{3} \mathrm{M}_{3}$.

Yield of processing grade tuber was the highest $(21.1 \mathrm{t} / \mathrm{ha})$ in $\mathrm{D}_{2}$ planting which was superior to all other dates of planting whereas percent contribution to total yield did not differ statistically (Table 3 ). That might be attributed to receive the longer period and optimum cold temperature during the bulking period resultant obtaining higher plant growth with the higher number and weight of tuber per hill. With regard to dehaulming, although a little higher yield of processing grade tuber was recorded at $\mathrm{M}_{3}$ in comparison to $\mathrm{M}_{2}$ but these differences were not statistically significant. Whereas, the lowest $(16.8 \mathrm{t} / \mathrm{ha})$ was exhibited in $\mathrm{M}_{1}$ dehaulming. But the percentage of processing grade tuber to total yield did differ statistically (Table 3). There was consistent increase in per cent of processing grade tubers with delay in dehaulming from 80 to 100 DAP and was highest 
Table 3. Effect of dates of planting and dehaulming on graded, total and percent of graded yield of potato

\begin{tabular}{|c|c|c|c|c|c|}
\hline \multirow[t]{2}{*}{ Treatments } & \multicolumn{3}{|c|}{ Grade wise tuber yield (t/ha) } & \multicolumn{2}{|c|}{$\begin{array}{c}\% \text { of grade wise tuber } \\
\text { yield }\end{array}$} \\
\hline & $<40 \mathrm{~mm}$ & $\geq 40 \mathrm{~mm}$ & Total & $<40 \mathrm{~mm}$ & $\geq 40 \mathrm{~mm}$ \\
\hline \multicolumn{6}{|c|}{ A. Date of planting } \\
\hline $\mathrm{D}_{1}$ & $7.2 \mathrm{a}$ & $14.7 \mathrm{c}$ & $21.9 \mathrm{c}$ & $31.9 \mathrm{a}$ & $68.1 \mathrm{~b}$ \\
\hline $\mathrm{D}_{2}$ & $4.7 \mathrm{~b}$ & $21.1 \mathrm{a}$ & $25.8 \mathrm{a}$ & $17.6 \mathrm{~b}$ & $82.4 \mathrm{a}$ \\
\hline $\mathrm{D}_{3}$ & $4.7 \mathrm{~b}$ & $18.6 \mathrm{~b}$ & $23.3 \mathrm{~b}$ & $19.3 \mathrm{~b}$ & $80.7 \mathrm{a}$ \\
\hline \multicolumn{6}{|c|}{ B. Dehaulming schedule } \\
\hline $\mathrm{M}_{1}$ & $6.5 \mathrm{a}$ & $16.8 \mathrm{~b}$ & 23.3 & $27.6 \mathrm{a}$ & $72.4 \mathrm{c}$ \\
\hline $\mathrm{M}_{2}$ & $5.8 \mathrm{~b}$ & $18.3 \mathrm{ab}$ & 24.1 & $23.5 \mathrm{~b}$ & $76.5 \mathrm{~b}$ \\
\hline $\mathrm{M}_{3}$ & $4.3 \mathrm{c}$ & $19.3 \mathrm{a}$ & 23.6 & $17.6 \mathrm{c}$ & $82.4 \mathrm{a}$ \\
\hline \multicolumn{6}{|c|}{ Interaction between A \& B } \\
\hline $\mathrm{D}_{1} \mathrm{M}_{1}$ & $8.8 \mathrm{a}$ & $11.3 \mathrm{e}$ & $20.1 \mathrm{~d}$ & $41.8 \mathrm{a}$ & $58.2 \mathrm{e}$ \\
\hline $\mathrm{D}_{1} \mathrm{M}_{2}$ & $8.4 \mathrm{a}$ & $14.5 \mathrm{~d}$ & $22.9 \mathrm{c}$ & $35.2 \mathrm{~b}$ & $64.8 \mathrm{~d}$ \\
\hline $\mathrm{D}_{1} \mathrm{M}_{3}$ & $4.5 \mathrm{c}-\mathrm{e}$ & $18.2 \mathrm{c}$ & $22.7 \mathrm{c}$ & $18.8 \mathrm{~cd}$ & $81.2 \mathrm{bc}$ \\
\hline $\mathrm{D}_{2} \mathrm{M}_{1}$ & $5.4 \mathrm{~b}$ & $20.9 \mathrm{ab}$ & $26.3 \mathrm{a}$ & $20.1 \mathrm{~cd}$ & $80.0 \mathrm{bc}$ \\
\hline $\mathrm{D}_{2} \mathrm{M}_{2}$ & $4.7 \mathrm{~b}-\mathrm{d}$ & $21.4 \mathrm{a}$ & $26.1 \mathrm{a}$ & $17.4 \mathrm{~cd}$ & $82.6 \mathrm{ab}$ \\
\hline $\mathrm{D}_{2} \mathrm{M}_{3}$ & $3.8 \mathrm{e}$ & $21.5 \mathrm{a}$ & $25.3 \mathrm{ab}$ & $14.3 \mathrm{e}$ & $85.7 \mathrm{a}$ \\
\hline $\mathrm{D}_{3} \mathrm{M}_{1}$ & $5.1 \mathrm{bc}$ & $18.5 \mathrm{c}$ & $23.6 \mathrm{bc}$ & $20.9 \mathrm{c}$ & $79.2 \mathrm{c}$ \\
\hline $\mathrm{D}_{3} \mathrm{M}_{2}$ & $4.2 \mathrm{de}$ & $19.2 \mathrm{bc}$ & $23.4 \mathrm{c}$ & $17.2 \mathrm{de}$ & $82.8 \mathrm{ab}$ \\
\hline $\mathrm{D}_{3} \mathrm{M}_{3}$ & $4.7 \mathrm{~b}-\mathrm{d}$ & $18.1 \mathrm{c}$ & $22.8 \mathrm{c}$ & $19.8 \mathrm{~cd}$ & $80.2 \mathrm{bc}$ \\
\hline $\mathrm{CV}(\%)$ & 8.03 & 5.82 & 4.39 & 8.18 & 2.43 \\
\hline $\mathrm{SE}(\mathrm{A} \times \mathrm{B})$ & 0.34 & 0.64 & 0.39 & 1.72 & 1.72 \\
\hline
\end{tabular}

Figure(s) in a column having common letter(s) do not differ significantly at $5 \%$ level by DMRT.

$<40 \mathrm{~mm}=$ Non processing grade tuber, $\geq 40 \mathrm{~mm}=$ Processing grade tuber .

$\mathrm{D}_{1}=31$ October, $\mathrm{D}_{2}=15$ November $\& \mathrm{D}_{3}=30$ November , and $\mathrm{M}_{1}=80$ days after planting (DAP), $\mathrm{M}_{2}=90 \mathrm{DAP}, \mathrm{D}_{3}=100 \mathrm{DAP}$.

(around 82\%) when dehaulming was done at 100 DAP then it declined significantly up to 80 DAP. It has been ascribed that the increase the proportion of processing grade tuber probably mainly because of the lengthening the growing period that resulted more accumulation of photosynthates in the tuber and ultimately increase larger tuber. The results are in agreement with Sandhu et al. (2012) where they reported that total and processing grade tuber yield 
increased significantly as the crop duration was increased from 70 to 90 days. Where the proportion of processing grade tubers yield was increased in 39\% and $28 \%$ and total yield was increased in $19 \%$ and $9 \%$ when the crop was dehaulmed at 70 to 80 and 80 to 90 days after planting, respectively. Significant variation was observed among the treatment combinations in processing grade tuber yield (Table 3). The results show that significantly higher yield of processing grade tuber was observed in $\mathrm{D}_{2}$ planting under all the dehaulming dates. Whereas, the lowest processing grade tuber yield $(11.3 \mathrm{t} / \mathrm{ha})$ was recorded in $\mathrm{D}_{1} \mathrm{M}_{1}$ which was around $58 \%$ of the total yield. The data shows that, the processing grade tuber yield was statistically similar in $\mathrm{D}_{2}$ planting under all the dehaulming dates but their per cent contributions to total yield was statistically differed. The highest proportion of processing grade tuber yield (around 86\%) was obtained in $\mathrm{D}_{2} \mathrm{M}_{3}$ which was statistically similar to $\mathrm{D}_{3} \mathrm{M}_{2}$ (around 83\%) and $\mathrm{D}_{2} \mathrm{M}_{2}$ (around $83 \%$ ). Kushwah and Govindakrisnan (1993) reported that maximum tubreization takes place at mean temperatures of day and night about $20^{\circ} \mathrm{C}$ and it was inhibited at day temperatures above $29^{\circ} \mathrm{C}$. Our results are in favour of this statement, in $\mathrm{D}_{2} \mathrm{M}_{2}$ and $\mathrm{D}_{2} \mathrm{M}_{3}$ treatment combination were received just mean temperatures of around $20^{\circ} \mathrm{C}$ in their tuberization and maturation period that might be helped in good processing grade tuber formation and on the contrary in $\mathrm{D}_{3} \mathrm{M}_{3}$ combination was fetched above $29^{\circ} \mathrm{C}$ temperatures resulting the lower processing grade as well as total yield.

The data of the table 3 shows that total yield was followed the exact same trend of processing grade tuber yield. The highest total yield $(25.9 \mathrm{t} / \mathrm{ha})$ was recorded in $\mathrm{D}_{2}$ planting than all other dates of planting. The second highest total yield (23.2 $\mathrm{t} / \mathrm{ha}$ ) was observed in $\mathrm{D}_{3}$ planting followed by $\mathrm{D}_{1}$ planting $(21.9 \mathrm{t} / \mathrm{ha})$ and these were statistically significant. The lower yield at earlier planting $\left(\mathrm{D}_{1}, 31\right.$ October) might be due to exposure of crop to high temperature at the time of planting and early growth period (Roy and Jaiswal, 1998; Singh et al., 1974) and has received short duration of low temperature in bulking period. The highest yield at November 15 planting has been reported under similar climatic and edaphic conditions by Akhter et al. (2013). The results also corroborated with Singh et al. (2004) where they reported that planting at 5 November decreased not only the total and processing grade tubers, but also the percentage of the processing grade tubers in the total tuber yield at Modipuram, India. For dehaulming, it was observed that although a little higher total yield $(24.1 \mathrm{t} / \mathrm{ha})$ was recorded in $\mathrm{M}_{2}$ dehaulming closely followed by $\mathrm{M}_{3}$ dehaulming (23.6 $\left.\mathrm{t} / \mathrm{ha}\right)$ and $\mathrm{M}_{1}$ dehaulming $(23.4 \mathrm{t} / \mathrm{ha})$, these differences were not statistically significant (Table 3). There was significant variation among treatment combinations in total tuber yield (Table 3 ). The results showed that significantly higher total yield was observed in $\mathrm{D}_{2}$ planting under all the dehaulming dates and the second higher total yield was recorded in $\mathrm{D}_{3}$ planting under all the 
dehaulming dates except $\mathrm{M}_{3}$. The results also showed that third higher total yield was recorded in $\mathrm{D}_{1}$ planting under all the dehaulming schedules except $\mathrm{M}_{1}$ with the $\mathrm{D}_{3}$ planting in combination with $\mathrm{M}_{3}$. Whereas, the lowest total yield (20.1 $\mathrm{t} / \mathrm{ha}$ ) was obtained in $\mathrm{D}_{1}$ planting with $\mathrm{M}_{1}$ dehaulming. Short period of low and high prevailing temperature might have limited tuber bulking in $D_{1}$ and $D_{3}$ planted crop, respectively.

\section{Processing quality parameters}

For processing potatoes into chips and French fries, dry matter content should be $20 \%$ or above because it determines the recovery of finished products, oil uptake and energy consumption for frying (Ezekiel et al., 1999; Gaur et al., 1999; Marwaha et al., 2005). Potato tuber dry matter, sugar and reducing sugar content mostly influenced by the varietal genetic make up but environmental and cultural factors are reported to affect the resulting sugar accumulation in freshly harvested tubers (Sowokinos, 1973). The results show that specific gravity and dry matter content were followed the same trend by the date of planting and

dehaulming and their interaction (Table 4). The highest specific gravity as well as dry matter content (1.089 and $22.6 \%$, respectively) was observed in $\mathrm{D}_{2}$ planting followed by $\mathrm{D}_{1}$ planting (1.086 and $22.0 \%$, respectively) whereas, the lowest specific gravity (1.083) and dry matter $(21.4 \%)$ was recorded in $\mathrm{D}_{3}$ planting (Table 4). These findings are in line with earlier works of Akhter et al. (2013) who reported higher dry matter and chipping quality were obtained in November 15 planting. In case of dehaulming, both specific gravity and dry matter content (1.087 and $22.3 \%$, respectively) were higher in tubers $\mathrm{M}_{1}$ which was at par with $\mathrm{M}_{2}$ and the lowest (1.085 and $21.7 \%$, respectively) was obtained in $\mathrm{M}_{3}$. The highest specific gravity (1.090) as well as dry matter content (22.9 $\%$ ) was recorded in $\mathrm{D}_{2} \mathrm{M}_{2}$ followed by $\mathrm{D}_{2} \mathrm{M}_{3}$ (1.090 and $22.8 \%$, respectively), $\mathrm{D}_{2} \mathrm{M}_{1}$ (1.087, and $22.2 \%$, respectively) and $\mathrm{D}_{1} \mathrm{M}_{1}(1.088$ and $22.6 \%$, respectively). Whereas, the lowest specific gravity (1.081) and dry matter content $(21.0 \%)$ was obtained in $\mathrm{D}_{3} \mathrm{M}_{3}$. It may be occurred in this combination due to slightly higher temperatures in the mid of spring season could have resulted in faster maturity of foliage and lesser translocation of dry matter in tubers in the last phase of crop life which ultimately lower the dry matter content (Kumar et al., 2007; Marinus and Bodlaender, 1975). The level of reducing sugars in potato tuber is an important factor affecting the colour of processed products (Roe et al., 1990). The contents of reducing sugars should be below $200 \mathrm{mg} / 100 \mathrm{~g}$ fresh weight for producing acceptable quality chips while for French fries the upper limit may be as high as $500 \mathrm{mg} / 100 \mathrm{~g}$ fresh weight (Ezekiel et al., 2003). The results showed that the reducing sugar content was much lower than the acceptable limit for processing into chips and French fries. 
Table 4. Effect of dates of planting and dehaulming on processing quality of potato

\begin{tabular}{|c|c|c|c|c|}
\hline Treatments & Specific gravity & Dry matter $(\%)$ & $\begin{array}{l}\mathrm{RS}(\mathrm{mg} / 100 \mathrm{~g} \\
\text { fresh wt.) }\end{array}$ & $\begin{array}{c}\text { Chip colour } \\
\text { score }\end{array}$ \\
\hline \multicolumn{5}{|l|}{ A. Date of planting } \\
\hline $\mathrm{D}_{1}$ & $1.086 \mathrm{~b}$ & $22.0 \mathrm{~b}$ & $36.5 \mathrm{~b}$ & 3.1 \\
\hline $\mathrm{D}_{2}$ & $1.089 \mathrm{a}$ & $22.64 \mathrm{a}$ & $32.5 \mathrm{c}$ & 3.0 \\
\hline $\mathrm{D}_{3}$ & $1.083 \mathrm{c}$ & $21.4 \mathrm{c}$ & $41.1 \mathrm{a}$ & 3.2 \\
\hline \multicolumn{5}{|c|}{ B. Dehaulming schedule } \\
\hline $\mathrm{M}_{1}$ & $1.087 \mathrm{a}$ & $22.3 \mathrm{a}$ & $34.9 \mathrm{~b}$ & 3.1 \\
\hline $\mathrm{M}_{2}$ & $1.086 \mathrm{ab}$ & $22.0 \mathrm{ab}$ & $37.5 \mathrm{a}$ & 3.1 \\
\hline $\mathrm{M}_{3}$ & $1.085 \mathrm{~b}$ & $21.7 \mathrm{~b}$ & $37.6 \mathrm{a}$ & 3.2 \\
\hline \multicolumn{5}{|c|}{ Interaction between A \& B } \\
\hline $\mathrm{D}_{1} \mathrm{M}_{1}$ & $1.088 \mathrm{ab}$ & $22.6 \mathrm{ab}$ & $37.7 \mathrm{c}$ & 3.1 \\
\hline $\mathrm{D}_{1} \mathrm{M}_{2}$ & $1.087 \mathrm{~b}$ & $22.1 \mathrm{~b}$ & $37.3 \mathrm{c}$ & 3.1 \\
\hline $\mathrm{D}_{1} \mathrm{M}_{3}$ & $1.083 \mathrm{c}$ & $21.4 \mathrm{c}$ & $34.5 \mathrm{~d}$ & 3.2 \\
\hline $\mathrm{D}_{2} \mathrm{M}_{1}$ & $1.087 \mathrm{ab}$ & $22.2 \mathrm{ab}$ & $33.0 \mathrm{e}$ & 3.1 \\
\hline $\mathrm{D}_{2} \mathrm{M}_{2}$ & $1.090 \mathrm{a}$ & $22.9 \mathrm{a}$ & $31.7 \mathrm{f}$ & 3.0 \\
\hline $\mathrm{D}_{2} \mathrm{M}_{3}$ & $1.090 \mathrm{a}$ & $22.8 \mathrm{a}$ & $32.8 \mathrm{e}$ & 3.1 \\
\hline $\mathrm{D}_{3} \mathrm{M}_{1}$ & $1.086 \mathrm{~b}$ & $22.0 \mathrm{~b}$ & $34.1 \mathrm{~d}$ & 3.2 \\
\hline $\mathrm{D}_{3} \mathrm{M}_{2}$ & $1.082 \mathrm{c}$ & $21.1 \mathrm{c}$ & $43.5 \mathrm{~b}$ & 3.2 \\
\hline $\mathrm{D}_{3} \mathrm{M}_{3}$ & $1.081 \mathrm{c}$ & $21.0 \mathrm{c}$ & $45.6 \mathrm{a}$ & 3.2 \\
\hline $\mathrm{CV}(\%)$ & 0.34 & 3.73 & 7.33 & 8.05 \\
\hline
\end{tabular}

Figure(s) in a column having common letter(s) do not differ significantly at $5 \%$ level by DMRT.

$\mathrm{D}_{1}=31$ October, $\mathrm{D}_{2}=15$ November $\& \mathrm{D}_{3}=30$ November $;$ and $\mathrm{M}_{1}=80$ days after planting (DAP), $\mathrm{M}_{2}=90 \mathrm{DAP}, \mathrm{D}_{3}=100 \mathrm{DAP} ; \mathrm{RS}=$ Reducing sugar

The highest reducing sugar $\left(41.1 \mathrm{mg} / 100 \mathrm{~g}\right.$ fresh wt.) was obtained in $\mathrm{D}_{3}$ planting followed by $\mathrm{D}_{1}$, while the lowest $\left(32.5 \mathrm{mg} / 100 \mathrm{~g}\right.$ fresh wt.) was recorded in $\mathrm{D}_{2}$ planting (Table 4). In case of dehaulming, the highest reducing sugar (37.6 $\mathrm{mg} / 100 \mathrm{~g}$ fresh wt.) was obtained in $\mathrm{M}_{3}$ which was statistically similar to $\mathbf{M}_{2}$. While the lowest $\left(34.9 \mathrm{mg} / 100 \mathrm{~g}\right.$ fresh wt.) was recorded in $\mathbf{M}_{1}$. The highest reducing sugar $\left(45.6 \mathrm{mg} / 100 \mathrm{~g}\right.$ fresh wt.) was recorded in $\mathrm{D}_{3} \mathrm{M}_{3}$ followed by $\mathrm{D}_{3} \mathrm{M}_{2}$, while, the lowest reducing sugar $(31.7 \mathrm{mg} / 100 \mathrm{~g}$ fresh wt.) was obtained in $\mathrm{D}_{2} \mathrm{M}_{2}$ followed by $\mathrm{D}_{2} \mathrm{M}_{3}$ and $\mathrm{D}_{2} \mathrm{M}_{1}$. Reducing sugar content was increased in $\mathrm{D}_{3} \mathrm{M}_{2}$ and $\mathrm{D}_{3} \mathrm{M}_{3}$ might be due to effect of high soil temperature. Timm et al. (1968) reported that sugar content increases if tuber is exposed to soil temperatures above $25^{\circ} \mathrm{C}$. Chips colour, the most important visual criterion for evaluating the quality of fried products, was mainly dependent on Millard 
reaction between reducing sugars and amino acids present in the tuber (Roe et al., 1990; Marwaha, 1999). The results showed that chips colour scores were remained significantly unaffected by date o planting, dehaulming schedule and their interaction (Table 4). The chips colour scores were around 3 which belong to acceptable range. However, Kumar et al. (2003) categorized the chips colour as a score of 1-2 are considered excellent, 3-4 are considered good and >5 is considered unacceptable.

Table 5. Economics of processing potato production as influenced by dates of planting and dehaulming

\begin{tabular}{c|c|c|c|c}
\hline Treatments & $\begin{array}{c}\text { Total cost of production } \\
(\mathrm{Tk} / \mathrm{ha})\end{array}$ & $\begin{array}{c}\text { Gross return } \\
(\mathrm{Tk} / \mathrm{ha})\end{array}$ & $\begin{array}{c}\text { Net return } \\
(\mathrm{Tk} / \mathrm{ha})\end{array}$ & BCR \\
\hline $\mathrm{D}_{1} \mathrm{M}_{1}$ & $1,80,886$ & $2,22,176$ & 41,291 & 1.23 \\
$\mathrm{D}_{1} \mathrm{M}_{2}$ & $1,80,886$ & $2,66,933$ & 86,048 & 1.48 \\
$\mathrm{D}_{1} \mathrm{M}_{3}$ & $1,80,886$ & $3,00,149$ & $1,19,263$ & 1.66 \\
$\mathrm{D}_{2} \mathrm{M}_{1}$ & $1,80,886$ & $3,42,665$ & $1,61,779$ & 1.89 \\
$\mathrm{D}_{2} \mathrm{M}_{2}$ & $1,80,886$ & $3,49,290$ & $1,68,404$ & 1.93 \\
$\mathrm{D}_{2} \mathrm{M}_{3}$ & $1,80,886$ & $3,45,114$ & $1,64,228$ & 1.91 \\
$\mathrm{D}_{3} \mathrm{M}_{1}$ & $1,80,886$ & $3,08,763$ & $1,27,877$ & 1.71 \\
$\mathrm{D}_{3} \mathrm{M}_{2}$ & $1,80,886$ & $3,12,447$ & $1,31,561$ & 1.73 \\
$\mathrm{D}_{3} \mathrm{M}_{3}$ & $1,80,886$ & $2,98,770$ & $1,17,884$ & 1.65 \\
\hline
\end{tabular}

Considering local market price of 2012-13, Urea, TSP, MOP, Gypsum, Zinc sulphate, Boric acid and cowdung @ Tk 15,23,17, 7, 170, 295 and 1/kg, respectively; Seed of potato@ Tk 30/kg, labour @ Tk 300/man-day; Sale of potato@ Tk 15/kg for $\geq 40$ mm and Tk 6/kg for <40 mm size; $\mathrm{D}_{1} \mathrm{M}_{1}=31$ October $\times 80 \mathrm{DAP} ; \mathrm{D}_{1} \mathrm{M}_{2}=31$ October $\times 90$ DAP $; \mathrm{D}_{1} \mathrm{M}_{3}=31$ October $\times 100 \mathrm{DAP} ; \mathrm{D}_{2} \mathrm{M}_{1}=15$ November $\times 80 \mathrm{DAP} ; \mathrm{D}_{2} \mathrm{M}_{2}=15$ November $\times 90 \mathrm{DAP} ; \mathrm{D}_{2} \mathrm{M}_{3}=15$ November $\times 100 \mathrm{DAP} ; \mathrm{D}_{3} \mathrm{M}_{1}=30$ November $\times 80$ $\mathrm{DAP} ; \mathrm{D}_{3} \mathrm{M}_{2}=30$ November $\times 90 \mathrm{DAP} ; \mathrm{D}_{3} \mathrm{M}_{3}=30$ November $\times 100 \mathrm{DAP}$

\section{Economics}

Cost of cultivation were remained same for all the treatment combinations because date of planting and dehaulming dates did not vary any input cost and the requirement of labourers (Table 5). Maximum gross returns $(\mathrm{Tk} 3,49,290)$ was recorded in $\mathrm{D}_{2} \mathrm{M}_{2}$ followed by $\mathrm{D}_{2} \mathrm{M}_{3}$ (Tk 3,45,114) and $\mathrm{D}_{2} \mathrm{M}_{1}(\mathrm{Tk} 3,42,665)$. The minimum gross return $(T k 2,22,176)$ was observed in $\mathrm{D}_{1} \mathrm{M}_{1}$. Net return showed marked difference among the treatment combinations and was followed the same trend of gross return as the total cost of cultivation was remained same in all the treatment combination. Net return was the highest $(\mathrm{Tk} 1,68,404)$ in $\mathrm{D}_{2} \mathrm{M}_{2}$ followed by $\mathrm{D}_{2} \mathrm{M}_{3}(\mathrm{Tk} 1,64,228)$ and $\mathrm{D}_{2} \mathrm{M}_{1}(\mathrm{Tk} 1,61,779)$ while the lowest $(\mathrm{Tk} 41,291)$ in $\mathrm{D}_{1} \mathrm{M}_{1}$. Higher net returns were mainly attributed to higher yield specially processing grade which got premium price associated with that treatment combinations. The maximum benefit cost ratio (BCR) (1.93) was obtained in $\mathrm{D}_{2} \mathrm{M}_{2}$ closely followed by $\mathrm{D}_{2} \mathrm{M}_{3}$ (1.91) and $\mathrm{D}_{2} \mathrm{M}_{1}$ (1.89) while the minimum (1.23) was 
in $D_{1} M_{1}$. The cost and return analysis revealed that November $15\left(D_{2}\right)$ planting regardless of dehaulming schedule economically superior to November 30 and October 31 planting in terms of net income and BCR.

\section{Conclusion}

The above results revealed that processing quality especially dry matter and reducing sugar differed significantly by dates of planting and dehaulming. Processing grade tuber yield were the higher in November 15 planting with all the dehaulming dates with high dry matter content and low reducing sugar. But we can prefer dehaulming at 90 DAP considering higher processing grade tuber yield with higher dry matter including higher net return and BCR. Besides it, the land can be available 10 days earlier for next crops without affecting processing quality and processing grade tuber yield as well as total yield. Based on the results of the experiment, it can be concluded that farmers at the areas of agroecological zone 28 can grow potato following November 15 planting time plus dehaulming at 90 days after planting for achieving higher processing grade tuber yield and net returns.

\section{Acknowledgement}

The authours are grateful to the authority of the Tuber Crops Development Project (BARI Part-II) for their financial support during the study period. Authours are also thankful to the Tuber Crops Research Center authority for facilitating to conduct the experiment.

\section{References}

Akhter, S., M. M. Islam, M. A. K. Azad, M. A. Hakim, M. S. Alam and M. W. Rahman. 2013. Effects of planting time and variety on the yield and processing quality of potato. J. Food, Agric. and Env. 11(1): 401-405.

Braun, J. V. 2010. Food insecurity, hunger and malnutrition: necessary policy and technology changes. Nat. Biotechnol. 27: 449-452.

Burton, W. G. 1989. Yield and content of dry matter: The underlying physiological processes. In: The Potato (W.G. Burton, Ed.). Longman Scientific and Technical, New York, USA. Pp. 84-155.

Ezekiel R., B. Singh and D. Kumar. 2003. A reference chart for potato chip colour for use in India. J. Indian Potato Asso. 30: 259-265.

Ezekiel, E. and S. C. Bhargava. 1992. Physiological analysis of growth of potato in relation to planting date. Indian J. Plant Physiol. 35(1): 56-63.

Ezekiel, R., S. C. Verma, N.P. Sukumaran and G.S. Shekhawat. 1999. A Guide to Potato Processors in India. Technical Bulletin No. 48, Central Potato Research Institute, Shimla, India. $39 \mathrm{p}$.

Gaur, P. C., S. K. Pandey, S. V. Singh and D. Kumar. 1999. Indian potato varieties for processing. Technical Bulletin No. 50, Central Potato Research Institute, Shimla, India. $25 \mathrm{p}$. 
Groves, S, J. Wiltshire, A. Briddon and A. Cunnington. 2005. Managing maturity to improve crop processing quality and storage. Project Report, British Potato Council, London, p 48. Available at: http://www.potato.org.uk/sites/default /files/\%5Bcurrentpage $\% 3$ Aarg\%3A\%3F\%5D/20055\%20Managing\%20Maturity\%20236\%20Final $\% 2$ Oreport.pdf (Accessed 12 December 2012)

Haverkort, A.J. 1990. Ecology of potato cropping systems in relation to latitude and altitude. Agricultural Systems. 32: 251-272.

Hossain, M. M., S. Akhter, M. K. R. Bhuiyan, E. H. M. S. Rahman, M. Hossain and S. N. Begum. 2007. Improved Production Technology of Potato (in Bengali). Tuber Crops Research Center, Bangladesh Agricultural Research Institute,Joydebpur, Gazipur. 6 p.

Krishnappa, K. S. 1991. Effect of planting time on the yield and yield attributes of potato in Eastern Karnataka. Current Res. 16: 239-40.

Kumar, D., S. V. Singh and S. K. Pandey. 2003. Chemical maturity of potato processing cultivars grown in western Uttar Pradesh. J. Indian Potato Assoc. 30(3-4): 225-32

Kumar, D., S. V. Singh, S. K. Pandey, B. P. Singh and S. Rawal. 2007. Effect of growing season on chipping quality of potatoes under sub-tropical climates. Potato J. 34(3-4): $180-86$

Kumar, D. and S. S. Lal. 2006. Effect of planting geometry, N and P levels and haulms cutting on the production of small size tubers of potato. Potato J. 33(1-2):97-98.

Kumar, P., B. P. Singh, R. Kumar, K. S. Sandhu, D. Kumar, S. K. Pandey and S. V. Singh. 2014. Optimizing crop geometry in Kufri Chipsona-3 and Kufri Himsona for higher grade tuber yield and quality. Potato J. 41(2):152-159.

Kushwah, V. S. and P. M. Govindakrishnan. 1993. Cultural practices for potato production. In: Advances in Horticulture Vol. 7- Potato. K. L. Chadha and J. S. Grewal (eds.). Malhotra Publishing House, New Delhi, India. Pp. 157-177.

Kushwah, V. S. and S. P. Singh. 2008. Effect of intra-row spacing and date of haulm cutting on production of small size tubers. Potato J. 35(1-2): 88-90.

Kushwah, V. S. and S. P. Singh. 2011. Relative performance of low input and high input technology for potato production in India. Potato J. 38(1): 56-60.

Lisinka, G. and W. Leszezynski. 1989. Potato Science and technology. Elsevier Applied Science, England. 391 p.

Marinus, J. and K. B. Bodlaender. 1975. Response of some potato varieties to temperature. Potato Res. 18: 189-204.

Marwaha, R. S., S. K. Pandey, S. V. Singh and S. M. P. Khurana. 2005. Processing and nutritional qualities of Indian and exotic potato cultivars as influenced by harvest date, tuber curing, pre-storage holding period, storage and reconditioning under short Days. Adv. Hort. Sci. 19(3): 130-40.

Marwaha, R. S. 1998. Factors determining processing quality and optimum processing maturity of potato cultivars grown under short days. J. Indian Potato Assoc. 25(3-4): 95-102.

Marwaha, R.S. 1999. Chipping quality and related processing characteristics of Indian potato varieties grown under short day conditions. J. Food Sci. Technol. 36(2): 157159. 
Muthuraj, R. and G. Ravichandran. 2014. Effect of date of planting on potato seed yield in the Indian southern hills. Potato J. 41(1): 91-93.

Muthuraj, R., G. Ravichandran, K. S. K. Prasad, and S. Singh. 2005. Effect of planting date on seed size tuber yield of potato in Nilgiris. Potato J. 32(3-4): 239.

Nelson N. 1944. A photometric adaption of the Somogy method for determination of glucose. J. Biol. Chem. 153:375-380.

Pandey, S. K., S. V. Singh, D. Kumar, R. S. Marwaha, P. Manivel and P. Kumar. 2008. Performance of newly released Kufri Chipsona-3 Indian potato variety during different crop seasons in west-central plains. Indian J. Agri. Sci. 78(2): 116-21

Peter, J., W. Cerng and L. Hruska, 1988. Yield Formation in the Main Field Crops. Elsevier Publication. Pp. 268-296

Prange, R.K., K.B. McRae, D.J. Midmore, and R. Deng. 1990. Reduction inpotato growth at high temperature: role of photosynthesis and dark respiration. Amer. Potato J. 67: 357-369.

Rodríguez-Falcón, M., J. Bou and S. Prat. 2006. Seasonal control of tuberization in potato. Ann. Re. Plant Biol. 57: 151-80.

Roe, M. A., R. M. Faulks and J. L. Beldtan. 1990. Role of reducing sugars and amino acids in fry colour of chips from potatoes grown in different regimes. J. Sci. Food Agri. 52: 207-214.

Roy, S. K. and V. P. Jaiswal. 1998. Response of potato (Solanum tuberosum) to planting dates and nitrogen. Indian J. Agron. 43(4): 484-488.

Sandhu, K. S., G. S. Chinna, R. S. Marwaha, S. K. Pandey, P. Kumar and R. K. Singh. 2012. Effect of staggered planting and dehaulming schedule on yield and processing quality of potato cultivars in Punjab. Potato J. 39(1): 39-47.

Singh, J. and S. C. Khurana. 1997. Effect of date of planting and gibberellic acid on potato seed crop. Haryana J. Hort. Sci. 25: 246-248.

Singh, P., M. Singh, A. K. Singh and J. S. Grewal. 1974. $25^{\text {th }}$ Annual Scientific Report. Central Potato Research Institute, Shimla, India. Pp. 39-41.

Singh, S. P. and V. S. Kushwah. 2010. Effect of size of seed tubers and date of haulm cuttings on production of small seed tubers. Potato J. 37(3-4): 167-170.

Singh, S. V., S. K. Pandey, D. Kumar and P. Kumar. 2004. Optimization of planting time of processing varieties of potato (Solanum tuberosum) in relation to yield and quality in west-central plains. Indian J. Agril. Sc. 74(12): 633-636.

Sowokinos, J. R. 1973. Maturation of Solanum tuberosum 1. comparative sucrose and sucrose synthetase levels between several good and poor processing varieties. Amer. Potato J. 50: 234-247.

Struik, P. C. and S. G. Wiersema. 1999. Seed Potato Technology. The Netherlands: Wageningen Pers.

Timm, H., M. Yamaguchi, M. D. Clegg and J. C. Bishop. 1968. Influence of high temperature exposure on sugar content and chipping quality of potatoes. Amer. Potato J. 45: 359-65.

Yamaguchi, M., H. Timm and A. R. Spurr. 1964. Effects of soil temperature on growth and nutrition on potato plants and tuberization, composition and periderm structure of tuber. Proc. Amer. Soc. Hort. Sci. 84: 412-23. 